THE EUROPEAN JOURNAL OF LIFE WRITING VOLUME VII(2018)R32-R34

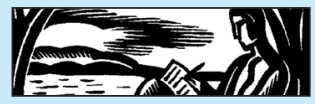

Sidonie Smith \& Julia Watson, Life Writing in the Long Run (Ann Arbor: Michigan Publishing/Maize Books, 2016, 730 pp., ISBN 9781607854098, open access version: http://dx.doi.org/10.3998/mpub.973996900)

\title{
Marijke Huisman
}

Utrecht University, the Netherlands

It is hard to imagine that readers of this journal would not be familiar with the works of Sidonie Smith and Julia Watson, the tandem of scholars from, respectively, the University of Michigan and Ohio State University who authored the successful textbook Reading Autobiography: A Guide for Interpreting Life Narratives (2001; 2010) and have been at the center of life writing studies for decades. Still, in the preface to their new book, the two write that 'emerging scholars or those in other fields reference predominantly the work of de Man, Barthes, and Lejeune, as if that triumvirate of theorists in the nineteen-seventies summed up the parameters of theorizing the autobiographical' (xx). This volume, subtitled 'A Smith \& Watson Autobiography Studies Reader', is meant to set the record straight and 'to bequeath the legacy of a past history of scholarly writing, not just our own but that of the many scholars whose work came before or alongside ours and who helped shape the arenas across disciplines in which the study of self-presentation and the narration of lived lives, have been and might be constructed' $(\mathrm{xx})$. Smith and Watson are the first to acknowledge that there is some hubris in this endeavor, but their main motivation for this collection is to introduce young or new scholars into the field that they have helped develop and mature.

Smith and Watson have assembled a retrospective that covers the period 1991-2016 and consists of solo essays, collaborative essays, and introductions to their edited volumes-from De/Colonizing the Subject: The Politics of Gender in Women's Autobiography (1992) to Before They Could Vote: American Women's Autobiographical Writing (2002). These 21 essays are presented in six thematic sections: Theoretical Frameworks; Everyday Lives and Autobiographical Storytelling; Enabling Concepts; Visualized Lives; Women's Life Writing in the United States, and Global Circuits, Political 
Formations. Within each section the articles are chronologically organized, but in reading the whole book from start to end, it is not always easy to grasp developments in the "legacy of a past history of scholarly writing' that Smith and Watson represent. They do, however, guide the reader into the field through 'A Personal Introduction to Life Writing in the Long Run'. Here the two explain how, in the eighties and nineties, the term 'autobiography' was increasingly criticized as being a reflection of 'the master narrative of the great Western "individual"' (xxii), and the new concept of 'life writing' was launched around 2000 to democratize the critical perspective and include self-presentations by people from different genders, cultures, and times. Smith and Watson, on the other hand, rightly point out that newcomers will often use terms like 'autobiography' in their searches for literature and therefore miss crucial information and studies. To what extent this volume's title helps to solve that issue is questionable, but it is doubtless that Life Writing in the Long Run can be used as an introduction to a field whose terminology was being reconsidered in the period in which the authors published their groundbreaking works.

Smith and Watson describe themselves as women who came of age in the late sixties (xxviii), and the progressive spirit of that era shines throughout the book. In the oldest piece (1991), the first lines read: 'All "I"s are not equal. Nor are they conceptualized similarly.' (305), and the volume testifies to the major impact of feminist and postcolonial perspectives on the field. In their introduction to Women, Autobiography, Theory: A Reader (1998), for instance, Smith and Watson discuss the then new ideas about the 'relationality' of autobiographical writings by women, and turn these into a more general critique of the gendered conception of an autonomous, individualist, and implicitly male subjectivity that dominated autobiography studies at the time. Influenced by French postmodern philosophers like Foucault, the two cautioned against essentialism in studies of 'women's autobiographical texts', but Smith and Watson also wished to recognize the cultural production of women and continued to work on women's life narratives. The volume therefore contains, among others, a collaborative essay on women's self-representations in visual art (2002) and an introduction on autobiographical writings by nineteenthcentury American women (2006).

The legacy of Smith and Watson also testifies to the impact of the "performative turn' on the field of autobiography/life writing studies. Part 3, Enabling Concepts, starts with an essay from 1995 in which Sidonie Smith relates autobiographical texts from Benjamin Franklin (1793) to Cherríe Morago (1983) to theoretical notions of performativity by Judith Butler, Jerome Bruner, and others. Smith argues for what now has become 
mainstream: that autobiographical story-telling is not a self-expressive act that unveils an identity that was already there, but that identities are made through the performance of narrating a life and that the form and contents of this performance depend on the cultural models and norms available to the writing subject. Throughout the volume, this perspective on life narratives is present in analyses of a wide and interesting range of self-presentations in textual, visual, and online media.

One example that returns in different essays is Tracy Emin's 'My bed' (1998), because Smith and Watson recognized this artistic installation as something that 'both flaunted and troubled the question of autobiographical acts by probing the boundaries of 'life' and 'art" (89-90). Moreover, the duo understands Emin's rumpled bed as a metaphor for the omnipresence of autobiographical acts in contemporary culture that begs for scholars of life writing to make sense of this 'messy multisensorium' (xlvii). Smith and Watson's collection provides plenty of useful theoretical and methodological insights for such a task. The two also show themselves to be great teachers, in translating sometimes difficult, abstract theories and concepts into practical analytical schemes that readers can work with. This hands-on approach shows immediately from essay titles like 'Witness or False Witness? Metrics of Authenticity, I-Formations and the Ethic of Verification in Testimony' (2012) and 'Virtually Me: A Toolkit about Online Self-Presentation' (2014), but is also present in many other essays. In order to facilitate classroom use of their book, Smith and Watson have even categorized their collection into a list of 20 topics that range from 'authenticity and agency' to 'visual portraiture, photography'.

Compiling a retrospective volume necessarily entails some backwardlooking, but Smith and Watson are as much engaged with the present and future as the past. This is most apparent in the introduction that frames the book. Here Smith and Watson do not only account for their choices in selecting the pieces for the volume, but they also present yet another scheme: an alphabetical list of prospects for further research. They argue, among other things, for more studies of relations between life writing and processes of globalization, relations between 'life' and 'writing' in a new media environment, and for studies at the intersection of life writing, human rights, and ethics. Thus, present and future scholars can find plenty of tools and inspiration in this volume that is also a monument for two leading scholars in our field. 